Review

\title{
Systematic review of foodborne burden of disease studies: Quality assessment of data and methodology
}

\author{
Juanita A. Haagsma a, ${ }^{\text {a, }}$, Suzanne Polinder ${ }^{\text {a }}$, Claudia E. Stein ${ }^{\text {b }}$, Arie H. Havelaar ${ }^{c, d}$ \\ a Erasmus MC, Department of Public Health, P.O. Box 2040, 3000 CA Rotterdam, The Netherlands \\ b Division of Information, Evidence, Research and Innovation, WHO Regional Office for Europe, Copenhagen, Denmark \\ ${ }^{c}$ National Institute for Public Health and the Environment, Centre for Zoonoses and Environmental Microbiology, P.0. Box 1, 3720 BA Bilthoven, The Netherlands \\ d University Utrecht, Institute for Risk Assessment Sciences, P.O. Box 80.178, 3508 TD Utrecht, the Netherlands
}

\section{A R T I C L E I N F O}

\section{Article history:}

Received 10 July 2012

Received in revised form 17 May 2013

Accepted 29 May 2013

Available online 13 June 2013

\section{Keywords:}

Systematic review

Burden of foodborne disease

DALY

Enteric pathogens

Parasitic pathogens

Chemical agents

\begin{abstract}
A B S T R A C T
Burden of disease (BoD) studies aim to identify the public health impact of different health problems and risk factors. To assess BoD, detailed knowledge is needed on epidemiology, disability and mortality in the population under study. This is particularly challenging for foodborne disease, because of the multitude of causative agents and their health effects. The purpose of this study is to systematically review the methodology of foodborne BoD studies. Three key questions were addressed: 1) which data sources and approaches were used to assess mortality, morbidity and disability?, 2) which methodological choices were made to calculate Disability Adjusted Life Years (DALY), and 3) were uncertainty analyses performed and if so, how? Studies (1990-June 2012) in international peer-reviewed journals and grey literature were identified with main inclusion criteria being that the study assessed disability adjusted life years related to foodborne disease. Twenty-four studies met our inclusion criteria. To assess incidence or prevalence of foodborne disease in the population, four approaches could be distinguished, each using a different data source as a starting point, namely 1) laboratory-confirmed cases, 2) cohort or cross-sectional data, 3) syndrome surveillance data and 4) exposure data. Considerable variation existed in BoD methodology (e.g. disability weights, discounting, age-weighting). Almost all studies analyzed the effect of uncertainty as a result of possible imprecision in the parameter values. Awareness of epidemiological and methodological rigor between foodborne BoD studies using the DALY approach is a critical priority for advancing burden of disease studies. Harmonization of methodology that is used and of modeling techniques and high quality data can enlarge the detection of real variation in DALY outcomes between pathogens, between populations or over time. This harmonization can be achieved by identifying substantial data gaps and uncertainty and establish which sequelae of foodborne disease agents should be included in BoD calculations.
\end{abstract}

(c) 2013 Elsevier B.V. All rights reserved.

\section{Contents}

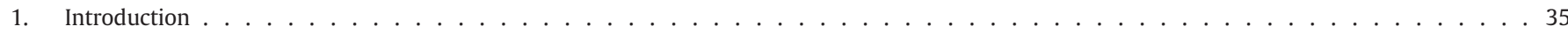

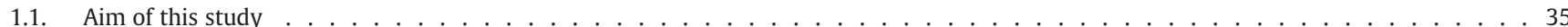

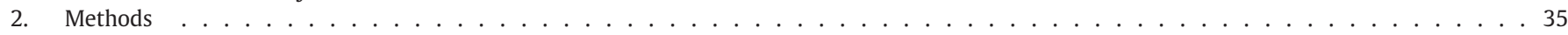

2.1. Selection criteria and definitions . . . . . . . . . . . . . . . . . . . . . . . . . . . . . . 35

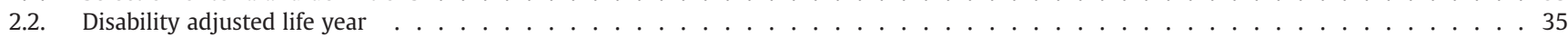

2.3. Foodborne disease model . . . . . . . . . . . . . . . . . . . . . . . . . . . . . . . . 35

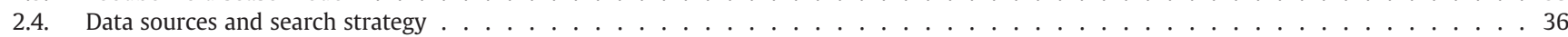

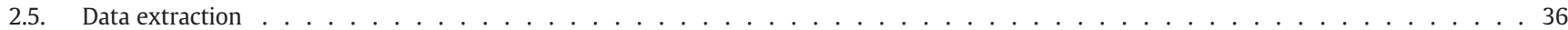

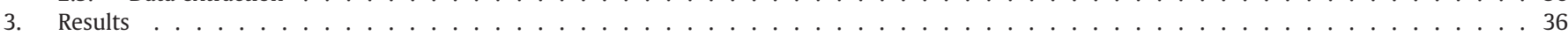

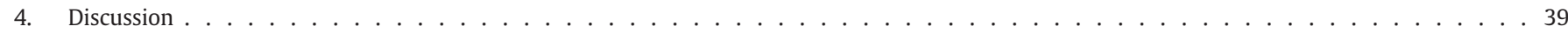

Abbreviations: BoD, Burden of disease; DALY, Disability adjusted life year; EMBASE, Excerpta Medica Databank; GBD, Global burden of disease and injury study; GP, General Practitioner; MeSH, Medical Subject Headings; SIGLE, System for Information on Grey Literature in Europe; WHO, World Health Organization; YLD, Years lived with disability; YLL, Years lost due to premature mortality.

* Corresponding author at: Erasmus MC, P.O. Box 2040, 3000 CA Rotterdam, The Netherlands. Tel.: +31 1070384 60; fax: +31 107038475

E-mail address: j.haagsma@erasmusmc.nl (J.A. Haagsma). 


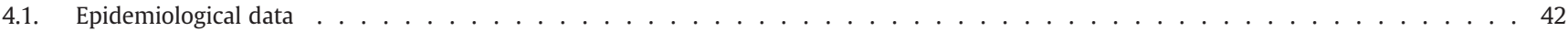

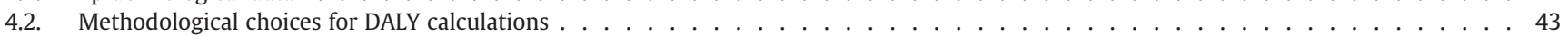

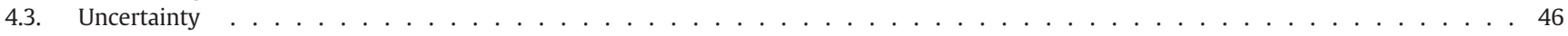

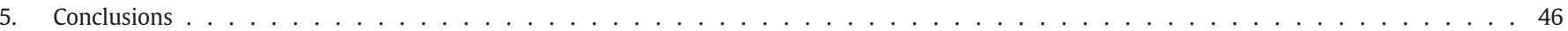

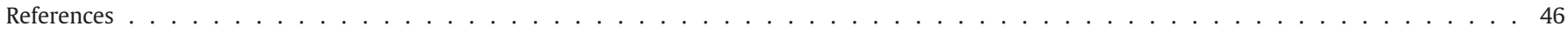

\section{Introduction}

Foodborne diseases encompass a wide spectrum of illnesses and are a growing public health problem worldwide (Tauxe et al., 2010). They are the result of ingesting contaminated foodstuffs, and range from diseases caused by a multitude of microorganisms to those caused by chemical hazards. The most common clinical presentation of foodborne diseases results in gastrointestinal symptoms, but foodborne diseases can also lead to chronic, life-threatening symptoms including neurological, gynecological or immunological disorders as well as multi-organ failure, cancer and death (WHO, 2007).

The burden of disease concept provides a methodological framework to quantify and compare the health of populations using the disability adjusted life year (DALY); a summary measure of population health that includes the effects of mortality, morbidity and disability. Morbidity here represents the presence of diseases and disability represents loss of function. A fundamental goal in assessing burden of disease is to identify the relative magnitude of different health problems and risk factors. This insight is significant for medical resource allocation and for targeting and monitoring possible impact of interventions in the food chain (Havelaar et al., 2007a; Mangen et al., 2010; Murray and Lopez, 1996; Worldbank, 1993). In principle, burden of disease analyses should provide DALY estimates based on the overall prevalence or incidence of morbidity and disabilities in the population. To achieve this, detailed knowledge is needed on epidemiology and health effects in the population under study (Anand and Hanson, 1997; Murray and Acharya, 1997). For foodborne disease this is particularly challenging, because of the multitude of causative agents and their health effects and the potentially broad span of time between exposure and symptoms. To deal with the lack of required epidemiological data profound statistical modelling has to be applied to assess the impact of foodborne disease on public health. In addition, the methodology of the burden of disease assessments is complex, both in concept and in application, and there are many methodological alternatives which affect DALY estimates, e.g. using alternative life expectancies, incidence- or prevalence-based estimates or alternative sets of disability weights.

\subsection{Aim of this study}

This systematic review aims to provide an overview of the methodology of foodborne burden of disease studies using the DALY approach. Three key questions were addressed: 1) which data sources and approaches were used to assess mortality, morbidity and disability?, 2) which methodological choices were made to calculate DALYs, and 3) were uncertainty analyses performed and if so, how?

\section{Methods}

The Global Burden of Disease (GBD) 1996 study used the DALY to estimate the total burden of disease worldwide as the sum of the burden of all separate diseases (Murray and Lopez, 1996). After this landmark study, a number of global and national burden of disease studies have been performed. The experiences of researchers involved in these studies served as a basis for a practical guide on burden of disease studies published by the World Health Organization (WHO) (Mathers et al., 2001). However, this practical guide does not address specific problems that arise when undertaking foodborne burden of disease studies. This review aims to complement the practical guide by collating the approaches of existing foodborne burden of disease studies.

\subsection{Selection criteria and definitions}

The systematic review was restricted to burden of disease studies relevant to foodborne disease. Foodborne diseases can be defined as those conditions that are commonly transmitted through ingested food. Foodborne diseases comprise a broad group of illnesses caused by microbial pathogens, parasites, chemical contaminants and bio toxins (WHO, 2008).

Empirical studies in international peer-reviewed journals and grey literature published in English in the period January 1990-June 2012 were included. Grey literature is defined as any material not identifiable through a traditional index or database, and includes for instance national reports, theses and unpublished studies (McKimmie and Szurmak, 2002). The review was restricted to studies using the DALY as burden of disease measure.

\subsection{Disability adjusted life year}

The DALY is calculated by adding the number of years of life lost due to mortality (YLL) to time spent in less than perfect health due to morbidity and disability, expressed in healthy year equivalents lost to disability (YLD) (Murray and Acharya, 1997). YLL is calculated by summation of the number of fatal cases $(d)$ due to health outcome $h$ in a certain period multiplied by the residual expected life expectancy $(e)$ at the age of death:

$Y L L=d_{h}^{*} e$

YLD is calculated by multiplying the number of incident cases (Inc) at a certain age with health outcome $\mathrm{h}$ by the duration of the health outcome $(t)$ and the disability weight $(d w)$ assigned to health outcome h:

$Y L D=I n c_{h}{ }^{*} t_{h}{ }^{*} d w_{h}$

If the prevalence-based approach is applied, than $\mathrm{YLD}_{\text {prev }}$ is calculated by multiplying the number of prevalent cases $(P)$ in age group ' $A$ ' at a point in the reference period with the disability weight $(d w)$ assigned to health outcome h:

$\mathrm{YLD}_{\text {prevA }}=P_{\mathrm{A}} * d w_{\mathrm{h}}$

The basic formulae can be supplemented due to methodological choices (e.g. expanding with a discount factor and applying age weighting) (Murray, 1994).

\subsection{Foodborne disease model}

Burden of disease studies relevant to foodborne disease may be subdivided into agent-based, outcome-based and risk factor-based 


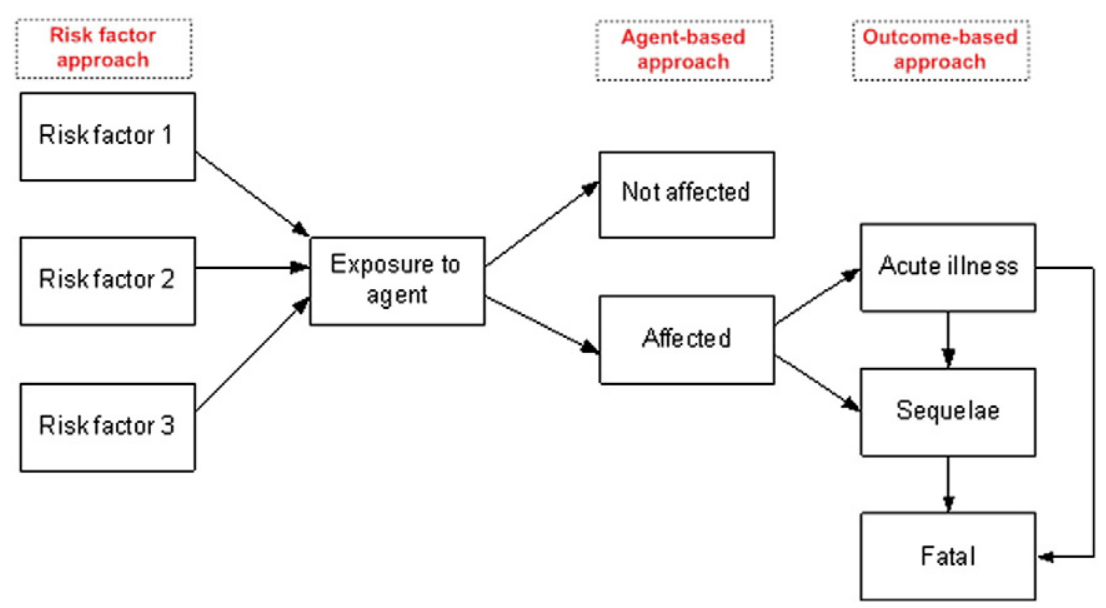

Fig. 1. Foodborne disease model.

studies, dependent on the perspective of the study (see Fig. 1). The agent-based approach covers all relevant health outcomes that can be attributed to one particular agent, including sequelae. A sequela is a pathological condition resulting from a prior disease, injury, or attack. The health outcomes may be subdivided in different disease categories. With the agent-based approach, the starting point of the burden of disease calculation is illness due to exposure to chemical contaminants or bio toxins or infection in case of microbial pathogens or parasites. To assess the disease burden of an agent, the complete disease burden that is attributable to this illness/infection is added up (Havelaar et al., 2000, 2012; Kretzschmar et al., 2012; Van Lier et al., 2007).

The outcome-based approach assigns the disease burden to clinically defined categories of diseases, irrespective of their cause (Kretzschmar et al., 2012; Van Lier et al., 2007).

With the risk factor approach, the burden of disease is attributed to health determinants and risk factors, such a unsafe water and lack of sanitation and hygiene (Kay et al., 2000). A risk factor is an attribute or exposure which is causally associated with an increased probability of a disease or injury (Murray and Lopez, 1996). In case of foodborne disease, a risk factor may affect exposure to agents that cause foodborne illness. One can attribute an adverse health outcome (e.g. disease case or fatality) to a single cause (causal attribution) or to a group of (counterfactual analysis) (Maldonado and Greenland, 2002).

\subsection{Data sources and search strategy}

Searches of eligible studies were conducted in Medline (PubMed), EMBASE and Web of Science. Searches for eligible grey literature were conducted in Google Scholar and SIGLE (System for Information on Grey Literature in Europe).

All international peer-reviewed articles and grey literature published in English in the period January 1990 to June 2012 were included in the searches.

Search terms used for burden of foodborne disease studies were: 'burden of disease', 'disability adjusted life year', 'DALY', 'foodborne diseases', 'parasite', 'diarrheal' and 'diarrhoeal', 'quality adjusted life years', 'disabled persons/statistics \& numerical data health status measure', and 'health status', 'cost of illness', 'morbidity', 'mortality', 'cohort studies'. Keywords were matched to database specific search terms (e.g. Medical Subject Headings (MeSH) terms).
In addition to database searches, reference lists of review studies and articles included in the review were screened for titles that included key terms.

Studies were included in the review if they met the following criteria:

- The subject of the study was burden of disease measurement of foodborne diseases and presenting DALY estimates;

- The burden of disease study was a general multiple cause study or specific burden of disease study relevant to foodborne disease;

- The articles were published in English.

\subsection{Data extraction}

Relevant papers were selected by screening the titles (first step), abstracts (second step) and entire articles (third step), retrieved through the database searches. During each step respectively the title, abstract or entire article was screened to ensure that it met the selection criteria listed above. This screening was conducted independently by two researchers (JH and SP). Disagreement about eligibility between the reviewers was solved through discussion.

Full articles were critically appraised by two reviewers (JH and SP), using data extraction forms, which included information on the study population, details regarding the methods used to calculate YLL and YLD, main conclusions etc. Their reports were compared and disagreements were resolved by discussion.

\section{Results}

Fig. 2 shows the flow diagram of the search of existing burden of disease studies and main reasons for exclusion. In total, 24 burden of disease studies related to foodborne disease were found. Six of these studies were global burden of disease studies (Fewtrell et al., 2005, 2004; Furst et al., 2012; Guerrant et al., 2002; Mathers et al., 2007; Pruss et al., 2002). Thirteen studies have been performed in Europe (Gkogka et al., 2011; Haagsma et al., 2008; Havelaar et al., 2000, 2012, 2007b, 2004, 2010; Kortbeek et al., 2009; Reij et al., 2009; Torgerson et al., 2008; Valent et al., 2004; Van Lier et al., 2007; Verhoef et al., 2012), and five studies were performed in Africa, South East Asia and the Western Pacific (i.e. Cameroon, South Africa, Bangladesh, Tibet, New Zealand). Table 1 shows the number of foodborne burden of disease studies per WHO region, subdivided into agent-based, outcome-based and risk-factor based approaches. The majority of burden of disease studies relevant to foodborne 


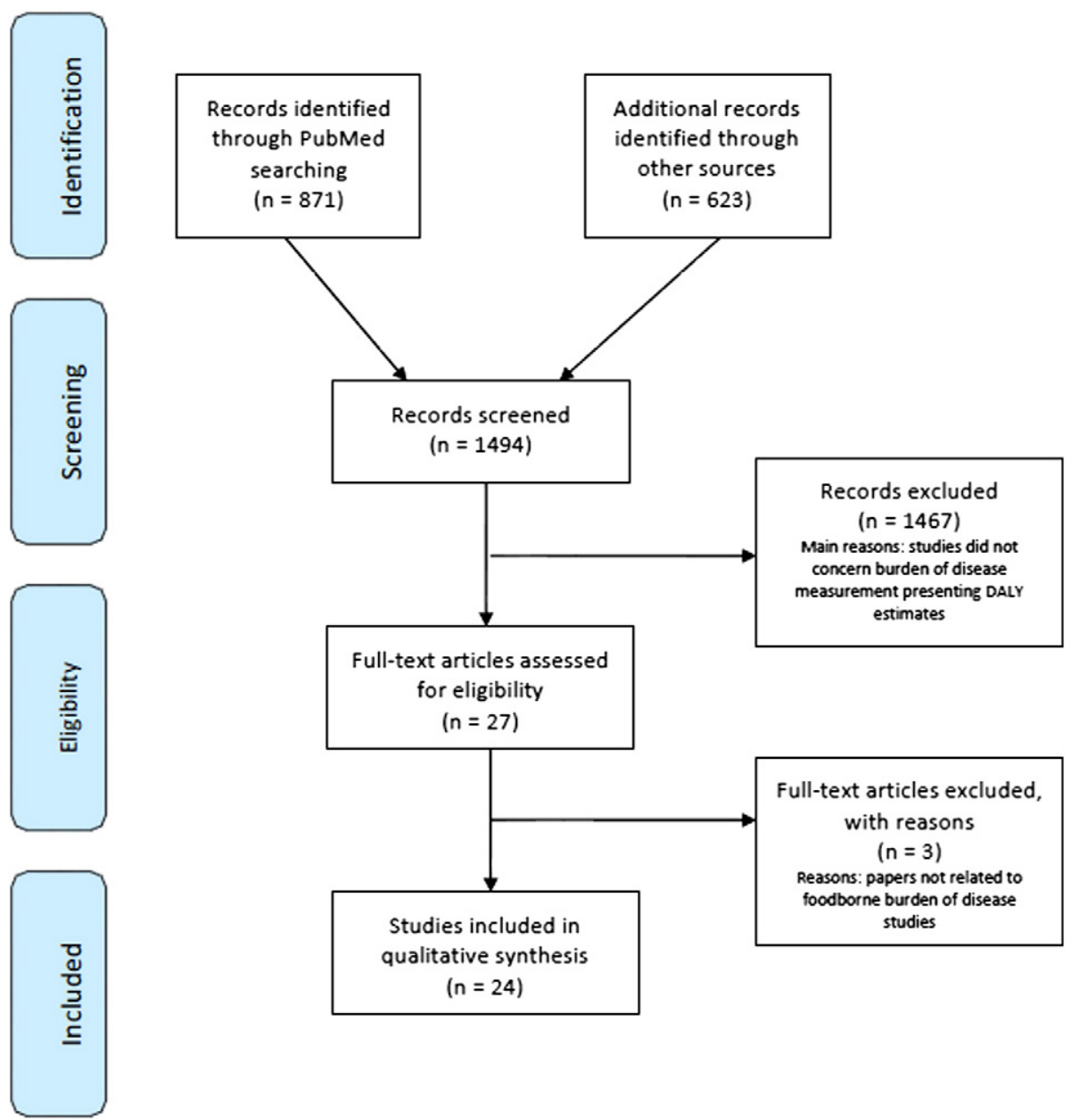

Fig. 2. Flow diagram of the search of existing burden of disease studies related to foodborne disease.

disease used the agent-based approach ( $\mathrm{n}=19$; (Budke et al., 2004; Fewtrell et al., 2005, 2004; Furst et al., 2012; Gkogka et al., 2011; Haagsma et al., 2008; Havelaar et al., 2000, 2012, 2007b, 2004; Kortbeek et al., 2009; Lake et al., 2010; Lokuge et al., 2004; Praet et al., 2009; Reij et al., 2009; Torgerson et al., 2008; Valent et al., 2004; Van Lier et al., 2007; Verhoef et al., 2012)).

1) Which data sources were used to assess mortality, morbidity and disability?

Table 2 presents a detailed overview of the data used to calculate YLL and YLD. It shows that often more than one data source is needed to assess incidence and prevalence regarding foodborne disease.

Data sources that were used to assess mortality to calculate YLL comprised vital registration data, case fatality ratios derived from literature (e.g. outbreak studies), demographic information or a combination of data sources. Seven studies reported that they corrected for underreporting of death statistics, for instance by modelling the proportion of undiagnosed cases (Budke et al., 2004) or by using case fatality ratios rather than reported deaths or by combining case fatality ratios and vital registration data (Gkogka et al., 2011; Havelaar et al., 2000, 2012, 2004; Verhoef et al., 2012). Van Lier et al. explored the effect of underreporting by scenario analysis (Van Lier et al., 2007). In case of missing data, literature was used to derive assumptions regarding the proportion and/or age distribution of fatal cases (Reij et al., 2009). Verhoef et al. used the age distribution of fatal cases from another country as proxy (Verhoef et al., 2012).
To assess incidence or prevalence of morbidity and disability, four approaches could be distinguished, each using a different data source as a starting point, namely a) laboratory-confirmed cases, b) cross-sectional data, c) syndrome surveillance or survey data and d) exposure data. Fig. 3 shows a schematic representation of the four approaches to estimate incidence.

a) From laboratory-confirmed cases to incidence

Six studies used laboratory-confirmed cases that were derived from passive surveillance systems (Gkogka et al., 2011; Havelaar et al., 2012; Lake et al., 2010; Torgerson et al., 2008; Van Lier et al., 2007; Verhoef et al., 2012). Subsequently, most studies applied scaling factors to estimate the total number of laboratoryconfirmed cases (i.e. accounting for underreporting), cases attending a GP and the total number of cases in the populations (i.e. accounting for underdiagnosis). The scaling factors are based on surveys, expert opinion or assumptions.

Data-quality-The data quality is dependent on the test sensitivity of the laboratory test used, the number of positive cases that are reported and the coverage rate of the surveillance system. The extrapolation of the laboratory confirmed cases is dependent on the information that is available for the scaling factors. One study did not extrapolate data (Van Lier et al., 2007), which, as acknowledged by the authors, means that data is restricted to cases reported in surveillance system, which most probably results in underreporting and underestimation of burden of disease. On the other hand, Gkogka et al. used multipliers for underreporting that were derived from studies in 
Table 1

Burden of disease studies relevant to foodborne disease $(n=24)$, subdivided into agent-based, outcome-based and risk-factor based approach.

\begin{tabular}{|c|c|c|c|c|}
\hline Agent-based & $\begin{array}{l}\text { Studies } \\
\left(n^{a}\right)\end{array}$ & References & WHO Region & Specific agents \\
\hline Enteric agents & 9 & $\begin{array}{l}\text { Gkogka et al. (2011), Haagsma et al. (2008), } \\
\text { Havelaar et al. (2000, 2004, 2012), Lake et al. } \\
\text { (2010), Reij et al. (2009), Van Lier et al. (2007), } \\
\text { Verhoef et al. (2012) }\end{array}$ & EURO, WPRO & $\begin{array}{l}\text { Campylobacter spp., Salmonella spp., Enterohaemorrhagic } \\
\text { E. coli, Listeria monocytogenes, Yersinia enterocolitica, } \\
\text { norovirus, rotavirus, Shiga Toxin-Producing E. coli } \mathbf{0 1 5 7 ,} \\
\text { Staphylococcus aureus, Bacillus cereus, Clostridium perfringens, } \\
\text { Hepatitis A virus, Hepatitis E virus, Cronobacter spp., } \\
\text { Clostridium botulinum, Brucella spp., Leptospira spp., Shigella spp. }\end{array}$ \\
\hline Parasitic agents & 8 & $\begin{array}{l}\text { Budke et al. (2004), Furst et al. (2012), } \\
\text { Gkogka et al. (2011), Havelaar et al. (2007b, } \\
\text { 2012), Kortbeek et al. (2009), Praet et al. } \\
\text { (2009), Torgerson et al. (2008) }\end{array}$ & EURO, WPRO, AFRO, Global & $\begin{array}{l}\text { Toxoplasma gondii, Giardia lamblia, Cryptosporidium parvum, } \\
\text { Echinoccosis, Taenia solium, Entamoeba histolytica, Trematodes }\end{array}$ \\
\hline Chemical agents & 4 & $\begin{array}{l}\text { Fewtrell et al. (2005, 2004), Lokuge et al. (2004), } \\
\text { Valent et al. (2004) }\end{array}$ & SEARO, EURO, Global & Lead, arsenicum \\
\hline Outcome-based & & & & Specific outcomes \\
\hline Communicable & 2 & Guerrant et al. (2002), Mathers et al. (2007) & Global & Diarrheal disease, tropical disease \\
\hline Non-communicable & 1 & Nafar et al. (2008) & EMRO & Chronic kidney disease \\
\hline Risk factor & & & & Specific risk factor \\
\hline $\begin{array}{l}\text { Environmental risk } \\
\text { factor }\end{array}$ & 2 & Lewin et al. (2007), Pruss et al. (2002) & AFRO, WPRO, Global & Unsafe water and lack of sanitation and hygiene \\
\hline
\end{tabular}

a Numbers add up to 26 studies, because Gkogka et al. (2011) and Havelaar et al. (2012) are included in two subgroups: enteric agents and parasitic agents.

other countries (Gkogka et al., 2011), which raises questions regarding the comparability of multipliers and health care systems of both countries. All studies that used laboratory-confirmed data as a starting point reported that data on severity, sequelae and excess mortality were not available.

b) From cohort data or cross-sectional data to incidence

Eight studies used cohort or cross-sectional data to estimate incidence (Budke et al., 2004; Haagsma et al., 2008; Havelaar et al., 2000, 2012, 2007b, 2004; Kortbeek et al., 2009; Verhoef et al., 2012). With this approach, data derived from a cohort or cross-sectional studies is used to calculate the number of patients that are infected. The data may consist of stool sample data (Haagsma et al., 2008; Havelaar et al., 2012; Verhoef et al., 2012), seroprevalence data (Havelaar et al., 2007b; Kortbeek et al., 2009) or ultrasound screening data (Budke et al., 2004). The number of positive cases is extrapolated to the whole population to assess incidence or prevalence, depending on the nature of the disease that is investigated, using scaling factors. The scaling factors are based on regional coverage and age composition of the cohort. If this approach is used to estimate prevalence, then a subsequent step that may be taken is to assess incidence in the population based on the estimate of prevalence.

Data-quality-The data quality is dependent on sensitivity of the tests used to assess the syndrome (e.g. abdominal ultrasound), the number and representativeness of the sample included in the surveillance or survey, geographical aspects (Is data collected in only a part of the region of study? Is this part of the region representative for the whole region?), availability and quality of data on the association of the agent and the syndrome and other aspects, such as stigmatization of the disease of interest, which may affect participation and/or reporting.

Information for the scaling factors may be very limited or crude, which raises questions about the validity of the extrapolations. Specific problems were that for some studies (part of) the cohort data was more than 10 years older than the year(s) to which the burden of disease estimates pertained to and that time-specific changes in infection rates were not accounted for. Other problems with data quality were that information on true positivity of cases, incidence and severity of complications and/or sequelae were not available.

c) From syndrome surveillance or survey data to incidence An important step of this approach is to assess the proportion of the cases attributable to the agent. This step is not taken with the approaches a and b. One study used survey data to assess prevalence (Praet et al., 2009); these survey data were extrapolated to the whole population to assess prevalence using scaling factors based on sample size and age composition of the cohort (Praet et al., 2009). The next step assesses the proportion of cases attributable to the agent and estimate incidence in the population.

Data quality: Issues with data quality are similar to those of approach b. Specific problems that were encountered in the study by Praet et al. were the high number of assumptions (Praet et al., 2009), because data for a number of crucial aspects of were not available (e.g. data on attribution, hospitalization, outpatient treatment, cases in the population and mortality).

d) From exposure to incidence

Five studies started with exposure to assess incidence or prevalence (Fewtrell et al., 2005, 2004; Lokuge et al., 2004; Reij et al., 2009; Valent et al., 2004). With this approach, regional exposure data are used to calculate exposure levels of a population. Scaling factors, based on sample size and age composition of the cohort, were applied to extrapolate exposure data to the whole population. Subsequently, levels of exposure are used to calculate the proportion of the population that is affected based on dose-response information. The proportion of affected population is then used to calculate prevalence or incidence in the population. Data-quality-The data quality of the exposure data is highly dependent on the availability, applicability and representativeness of the population of such studies. The methods that are used for sampling, measuring and reporting vary widely, impeding comparison and pooling of results. Quality of the methods and techniques were highly dependent on the region. Data for certain regions were missing and regional variation was not taken into account. Apart from that, the studies frequently are unclear whether samples were taken in rural or urban settings. Similarly to the approaches $\mathrm{a}, \mathrm{b}$ and $\mathrm{c}$, information for the scaling factors may be very limited or very crude. 
2) Which methodological choices were made in order to calculate YLL and YLD

General burden of disease methods

Table 3 presents a detailed overview of the methods used to calculate YLL and YLD.

Incidence or prevalence-based approach-Whether an incidence or prevalence-based approach is used is highly dependent on the goal of the study. The incidence-based approach reflects the future burden of disease based on current events, where all health outcomes, including those in future years, are assigned to the initial event. The prevalence-based approach reflects the current burden of disease based on previous events. In practice, it is often difficult to rigidly apply the incidence or prevalence-based approach and sometimes compromises must be made. The majority $(n=21)$ of burden of disease estimates were based on incidence data. The year to which the data applied varied from 1990 through 2009. Some studies used an average of cases over several years to calculate incidence to obtain a more stable estimate.

Age-weighting and discounting-With age-weighting the altering levels of productivity and dependency with age are taken into account, meaning that years lived at youngest and oldest age are given less weight, because at these ages a person is more dependent on others. Age-weighting was performed in ten studies (Budke et al., 2004; Fewtrell et al., 2004; Guerrant et al., 2002; Lokuge et al., 2004; Mathers et al., 2007; Nafar et al., 2008; Praet et al., 2009; Pruss et al., 2002; Torgerson et al., 2008; Valent et al., 2004). Discounting reflects the economic concept that immediate profits are generally preferred over benefits later in time (Murray and Lopez, 1996). When discounting is applied future life years are assigned less value than those lived today. Seventeen studies used a discount factor that varied between 1.5 and $4 \%$ (Bhutta et al., 2011; Budke et al., 2004; Fewtrell et al., 2005; Guerrant et al., 2002; Haagsma et al., 2008; Havelaar et al., 2000, 2012, 2007b, 2004; Lokuge et al., 2004; Mathers et al., 2007; Nafar et al., 2008; Praet et al., 2009; Pruss et al., 2002; Torgerson et al., 2008; Valent et al., 2004; Verhoef et al., 2012).

Methods to calculate YLL

Four studies did not calculate YLL, either because the health outcome under study did not result in fatality (mild mental retardation due to exposure to lead (Fewtrell et al., 2004); skin lesions due to exposure to arsenic (Valent et al., 2004)) or because YLL from a previous burden of disease study was used (Guerrant et al., 2002; Lewin et al., 2007).

The life expectancy that was used for the YLL calculations varied. Eight studies used the global life table, i.e. the West Level 26 (for women) and 25 (for men) life-tables, that were developed by GBD (Budke et al., 2004; Havelaar et al., 2000, 2012; Mathers et al., 2007; Praet et al., 2009; Pruss et al., 2002; Van Lier and Havelaar, 2007; Verhoef et al., 2012). Country specific life expectancy tables were also used by eight studies (Gkogka et al., 2011; Haagsma et al., 2008; Havelaar et al., 2004; Kortbeek et al., 2009; Lake et al., 2010; Nafar et al., 2008; Reij et al., 2009; Torgerson et al., 2008).

Methods to calculate YLD

Disability weights-A crucial aspect to calculate YLD is the disability weight; a value ranging from 1 , indicating worst imaginable health state equal to death, to 0 , indicating full health. Its value is based on the preferences of a panel of judges stated towards a set of hypothetical health states, expressing the relative undesirability of the health state (Drummond et al., 1997; Murray and Acharya, 1997). Following the GBD 1996 study, for which a large set of disability weights was derived (Murray and Lopez, 1996), other sets of disability weights have been developed. Often used alternative disability weights are the Dutch disability weights. Several studies reported that there were no disability weights available for particular health outcomes, such as human alveolar and cystic echinococcosis, foodborne trematodiasis and reactive arthritis. In these cases, proxy-disability weights, i.e. disability weights of health outcomes with similar health effects, were used (Budke et al., 2004; Furst et al., 2012) or a set of disability weights that was specifically derived for the study (Haagsma et al., 2008; Havelaar et al., 2012).

Sequelae-A second aspect in the assessment of burden of disease concerns the coverage of long-term health outcomes or sequelae. A sequela is a pathological condition resulting from a prior disease, injury, or attack. To satisfy the aspiration of an agent-based burden of disease studies, all sequelae should be taken into account. Most of the burden of foodborne disease studies ( $n=14$; (Budke et al., 2004; Gkogka et al., 2011; Guerrant et al., 2002; Haagsma et al., 2008; Havelaar et al., 2000, 2012, 2007b, 2004; Kortbeek et al., 2009; Lake et al., 2010; Praet et al., 2009; Reij et al., 2009; Torgerson et al., 2008; Van Lier et al., 2007) included sequelae in the YLD calculations. The number of cases that developed sequelae was calculated using probabilities derived from literature and sometimes supplemented by data from disease registries and/or specific studies. It should be noted that, between studies that estimated burden of disease of the same agent, there were differences regarding the sequelae that were included. Some studies on the burden of Campylobacter and Salmonella included post-infectious irritable bowel syndrome (Gkogka et al., 2011; Haagsma et al., 2008; Havelaar et al., 2012), whereas other studies did not take this sequela into account (Havelaar et al., 2000; Lake et al., 2010). Comorbidity adjustment-Two studies that adjusted for comorbidity applied a reduced life span in case of co-occurrence of listeriosis and other diseases (Havelaar et al., 2012; Verhoef et al., 2012). Mathers et al. corrected for comorbidity by adjusting the disability weights for common co-occurring disease (Mathers et al., 2007).

3) Which methods were used to handle uncertainty?

Each burden of disease study contains uncertainty as a result of possible imprecision in the model parameters that are used (parameter uncertainty), methodological controversy (model uncertainty) or systematic uncertainty and uncertainty due to a lack of data (structural uncertainty (Bilcke et al., 2011). Model uncertainty reflects the uncertainty around methodological choices and it can be evaluated by sensitivity analysis, which tests whether plausible changes in assumptions or model choices affect the results of the analysis (Murray and Lopez, 1996). Several studies $(n=7)$ performed such a sensitivity analysis, e.g. to evaluate the effect of including discounting and of different discount rates (Havelaar et al., 2012) or different life tables (Gkogka et al., 2011).

Structural uncertainty can be evaluated by scenario analysis. In a scenario analysis only one parameter will be changed at time, whereas all other parameters remain unchanged. Several studies applied scenario analysis, for instance to assess the effect of the inclusion of a certain sequela the calculation of the burden of disease (Havelaar et al., 2012), to estimate the long-term effect of diarrhoeal disease in children aged under 4 (Guerrant et al., 2002) or to analyze different prevalence rates or exposure (Praet et al., 2009; Pruss et al., 2002).

Parameter uncertainty can be specified with a probability distribution. Almost all studies analyzed the effect of parameter uncertainty with probabilistic analysis using Monte Carlo simulation.

\section{Discussion}

We systematically reviewed 24 burden of disease studies using the DALY approach and performed a quality assessment of the methodology used. The majority of the included studies comprised of agent-based foodborne burden of disease studies (75\%). We found that studies generally followed the GBD 1996 approach, which consists of using the incidence-based approach, GBD disability weights 
Table 2

Agent-based BoD studies related to foodborne disease ( $\mathrm{n}=19$ ): data sources used, quality of the data and extrapolation for YLD.

\begin{tabular}{|c|c|c|c|c|c|c|}
\hline Author, Year & Agent & Starting point & Data used & Extra-polation & Assumptions & Uncertainty \\
\hline Budke et al. (2004) Tibet & Echinococcosis & Cohort data & $\begin{array}{l}\text { Mortality: assumptions Morbidity: } \\
\text { prevalence data Duration: assumptions }\end{array}$ & Yes & $\begin{array}{l}\text { Progression, duration } \\
\text { and fatality }\end{array}$ & $\begin{array}{l}\text { Uncertainty of disability weights and } \\
\text { prevalence rates was modelled }\end{array}$ \\
\hline $\begin{array}{l}\text { Fewtrell et al. (2004) } \\
\text { Global }\end{array}$ & Lead & Exposure data & $\begin{array}{l}\text { Mortality and morbidity: } \\
\text { data on exposure }\end{array}$ & Yes & $\begin{array}{l}\text { Sample exposure is equal } \\
\text { to regional exposure }\end{array}$ & No \\
\hline $\begin{array}{l}\text { Fewtrell et al. (2005) } \\
\text { Global }\end{array}$ & Arsenicum & Exposure data & $\begin{array}{l}\text { Mortality:- Morbidity: exposure and } \\
\text { dose-response from literature }\end{array}$ & Yes & $\begin{array}{l}\text { Age distribution of exposed equal } \\
\text { to age distribution of the country } \\
\text { population; duration of } 10 \text { years }\end{array}$ & $\begin{array}{l}\text { Three prevalence scenarios } \\
\text { were formulated and uncertainty } \\
\text { was then modelled }\end{array}$ \\
\hline Furst et al. (2012) Global & Trematodes & Literature review & $\begin{array}{l}\text { Mortality: literature Morbidity: } \\
\text { literature Duration: literature }\end{array}$ & Yes & No remission & $\begin{array}{l}\text { Uncertainty was analyzed; } \\
\text { details are not available }\end{array}$ \\
\hline $\begin{array}{l}\text { Gkogka et al. (2011) } \\
\text { Greece }\end{array}$ & $\begin{array}{l}\text { Botulism, Bruccelosis, } \\
\text { Campylobacteriosis, EHEC, } \\
\text { Leptospirosis, Listeriosis, } \\
\text { Salmonellosis, Shigellosis, } \\
\text { Amebiasis, Cryptosporidiosis, } \\
\text { Echinococcosis, Giardiasis, } \\
\text { Toxoplasmosis, Hepatitis A }\end{array}$ & Laboratory confirmed cases & $\begin{array}{l}\text { Mortality: Case-fatality ratios } \\
\text { Morbidity: Laboratory confirmed } \\
\text { cases Duration: Literature }\end{array}$ & Yes & $\begin{array}{l}\text { Multipliers for seriousness } \\
\text { of illness }\end{array}$ & $\begin{array}{l}\text { Uncertainty caused by } \\
\text { underreporting and food } \\
\text { attribution were taken } \\
\text { into account }\end{array}$ \\
\hline $\begin{array}{l}\text { Haagsma et al. (2008) } \\
\text { The Netherlands }\end{array}$ & $\begin{array}{l}\text { Norovirus, rotavirus, Campylobacter spp., } \\
\text { Salmonella spp., and STEC } 0157\end{array}$ & Cohort data & $\begin{array}{l}\text { Mortality: literature Morbidity: } \\
\text { community-based and gp-based } \\
\text { cohort data Duration: literature }\end{array}$ & Yes & $\begin{array}{l}\text { Probabilities of death and } \\
\text { development of sequelae }\end{array}$ & $\begin{array}{l}\text { Uncertainty of incidence } \\
\text { was modelled }\end{array}$ \\
\hline $\begin{array}{l}\text { Havelaar et al. (2000) } \\
\text { The Netherlands }\end{array}$ & Campylobacter spp. & Cohort data & $\begin{array}{l}\text { Mortality: literature Morbidity: outbreak } \\
\text { reports, laboratory reports, GP-based } \\
\text { surveillance and population-based } \\
\text { surveys Duration: literature }\end{array}$ & Yes & $\begin{array}{l}\text { Probabilities of death and } \\
\text { development of sequelae }\end{array}$ & $\begin{array}{l}\text { Uncertainty of incidence } \\
\text { was modelled }\end{array}$ \\
\hline $\begin{array}{l}\text { Havelaar et al. (2004) } \\
\text { The Netherlands }\end{array}$ & STEC 0157 & Cohort data & $\begin{array}{l}\text { Mortality: literature Morbidity: } \\
\text { community-based and GP-based } \\
\text { cohort data Duration: literature }\end{array}$ & Yes & $\begin{array}{l}\text { Probabilities of death and } \\
\text { development of sequelae }\end{array}$ & $\begin{array}{l}\text { Uncertainty of incidence } \\
\text { was modelled }\end{array}$ \\
\hline $\begin{array}{l}\text { Havelaar et al. } \\
\text { (2007b) } \\
\text { The Netherlands }\end{array}$ & Toxoplasma gondii (congenital only) & Cohort data & $\begin{array}{l}\text { Mortality: literature Morbidity: } \\
\text { prospective cohort data and } \\
\text { cross-sectional sero-prevalence } \\
\text { data Duration: literature }\end{array}$ & Yes & $\begin{array}{l}\text { Probabilities of foetal loss and } \\
\text { development of sequelae }\end{array}$ & $\begin{array}{l}\text { Uncertainty of incidence } \\
\text { was modelled }\end{array}$ \\
\hline $\begin{array}{l}\text { Havelaar et al. (2012) } \\
\text { The Netherlands }\end{array}$ & $\begin{array}{l}\text { Campylobacter, Salmonella, norovirus, } \\
\text { rotavirus, STEC 0157, Staphylococcus } \\
\text { aureus, Bacillus cereus, Clostridium } \\
\text { perfringens, Giardia lamblia, Cryptosporidium } \\
\text { parvum, Listeria monocytogenes, Hepatitis }\end{array}$ & $\begin{array}{l}\text { Cohort data, laboratory } \\
\text { confirmed cases }\end{array}$ & $\begin{array}{l}\text { Mortality: literature Morbidity: } \\
\text { community-based and GP-based } \\
\text { cohort study and laboratory surveillance } \\
\text { system data Duration: literature }\end{array}$ & Yes & $\begin{array}{l}\text { Probabilities of death and } \\
\text { sequelae }\end{array}$ & $\begin{array}{l}\text { Uncertainty of incidence } \\
\text { was modelled }\end{array}$ \\
\hline
\end{tabular}




\begin{tabular}{|c|c|c|c|c|c|c|}
\hline $\begin{array}{l}\text { Kortbeek et al. (2009) } \\
\text { The Netherlands }\end{array}$ & Toxoplasma gondii (congenital only) & Cohort data & $\begin{array}{l}\text { Mortality: literature Morbidity: data } \\
\text { from cohort study Duration: literature }\end{array}$ & Yes & $\begin{array}{l}\text { Probabilities of foetal loss and } \\
\text { development of sequelae }\end{array}$ & $\begin{array}{l}\text { To account for uncertainty, low } \\
\text { values, most likely values and } \\
\text { high values were used for the } \\
\text { parameters }\end{array}$ \\
\hline $\begin{array}{l}\text { Lake et al. (2010) } \\
\text { New Zealand }\end{array}$ & $\begin{array}{l}\text { Campylobacteriosis, Salmonellosis, } \\
\text { Listeriosis, STEC infection, } \\
\text { Yersiniosis, norovirus infection }\end{array}$ & $\begin{array}{l}\text { Laboratory confirmed } \\
\text { cases }\end{array}$ & $\begin{array}{l}\text { Mortality: mortality data from health } \\
\text { services registries Morbidity: } \\
\text { surveillance data Duration: literature }\end{array}$ & Yes & $\begin{array}{l}\text { Probabilities of hospitalizations, } \\
\text { and sequelae; FBD attributions }\end{array}$ & $\begin{array}{l}\text { Uncertainty of the incidence } \\
\text { estimates was modelled }\end{array}$ \\
\hline $\begin{array}{l}\text { Lokuge et al. (2004) } \\
\text { Bangladesh }\end{array}$ & Arsenicum & Exposure data & $\begin{array}{l}\text { Mortality and morbidity: exposure and } \\
\text { dose-response from literature }\end{array}$ & Yes & $\begin{array}{l}\text { Sample exposure is equal to } \\
\text { regional exposure }\end{array}$ & No \\
\hline $\begin{array}{l}\text { Praet et al. (2009) } \\
\text { Cameroon }\end{array}$ & Taenia solium & Survey data & $\begin{array}{l}\text { Mortality: assumptions Morbidity: } \\
\text { prevalence data from population surveys } \\
\text { Durations: assumptions }\end{array}$ & Yes & $\begin{array}{l}\text { Attribution to NCC, hospitaliza- } \\
\text { tion, outpatient treatment, cases } \\
\text { in the population, mortality and } \\
\text { durations }\end{array}$ & $\begin{array}{l}\text { Three prevalence scenarios } \\
\text { were formulated and } \\
\text { uncertainty was then modelled }\end{array}$ \\
\hline $\begin{array}{l}\text { Reij et al. (2009) } \\
\text { The Netherlands }\end{array}$ & Cronobacter spp. & Exposure data & $\begin{array}{l}\text { Mortality: literature Morbidity: exposure } \\
\text { and dose-response Duration: European } \\
\text { Hospital Morbidity Database }\end{array}$ & Yes & $\begin{array}{l}\text { Exposure, dose-response } \\
\text { and underreporting factor }\end{array}$ & $\begin{array}{l}\text { Uncertainty in exposure and } \\
\text { dose response was modelled }\end{array}$ \\
\hline $\begin{array}{l}\text { Torgerson et al. (2008) } \\
\text { Switzerland }\end{array}$ & Human alveolar echinococcosis & Laboratory confirmed cases & $\begin{array}{l}\text { Mortality: Survival analysis Morbidity: } \\
\text { Laboratory confirmed cases Duration: } \\
\text { Survival analysis }\end{array}$ & No & $\begin{array}{l}\text { Excess hazard compared to the } \\
\text { Swiss population norms was } \\
\text { assumed to be due Human } \\
\text { alveolar echinococcosis }\end{array}$ & $\begin{array}{l}\text { Parameter uncertainty and } \\
\text { scenario analysis was performed }\end{array}$ \\
\hline $\begin{array}{l}\text { Valent et al. (2004) } \\
\text { Europe }\end{array}$ & Lead & Exposure data & $\begin{array}{l}\text { Mortality:- Morbidity: data on } \\
\text { exposure and literature }\end{array}$ & Yes & $\begin{array}{l}\text { Sample exposure is equal to } \\
\text { regional exposure; lead } \\
\text { prevention activities } \\
\text { reduce blood lead levels by } 8 \%\end{array}$ & $\begin{array}{l}\text { Three incidence scenarios were } \\
\text { formulated and uncertainty } \\
\text { was then modelled }\end{array}$ \\
\hline $\begin{array}{l}\text { Van Lier et al. (2007) } \\
\text { The Netherlands }\end{array}$ & $\begin{array}{l}\text { Influenza, measles, HIV, } \\
\text { Campylobacteriosis, EHEC infection, } \\
\text { Salmonellosis, Tuberculosis }\end{array}$ & Laboratory confirmed cases & $\begin{array}{l}\text { Mortality: mortality data Eurostat } \\
\text { Morbidity: surveillance data Eurostat } \\
\text { Duration: literature }\end{array}$ & No & $\begin{array}{l}\text { No mortality reported, then } \\
\text { mortality is zero; probabilities for } \\
\text { the development of sequelae }\end{array}$ & $\begin{array}{l}\text { For some diseases the effect of } \\
\text { underreporting was explored } \\
\text { by scenario analysis }\end{array}$ \\
\hline $\begin{array}{l}\text { Verhoef et al. (2012) } \\
\text { The Netherlands }\end{array}$ & Norovirus & $\begin{array}{l}\text { Cohort data } \\
\text { (community-acquired } \\
\text { cases), laboratory confirmed } \\
\text { cases (outbreak cases) }\end{array}$ & $\begin{array}{l}\text { Mortality: case-fatality ratios Morbidity: } \\
\text { cohort data, registry for hospitalization, } \\
\text { laboratory surveillance data of hospitalized } \\
\text { cases and passive laboratory surveillance } \\
\text { Duration: literature }\end{array}$ & Yes & $\begin{array}{l}\text { Proportion outbreak cases that } \\
\text { visit a GP }\end{array}$ & $\begin{array}{l}\text { Uncertainty of incidence was } \\
\text { modelled }\end{array}$ \\
\hline
\end{tabular}


and applying discounting and/or age-weighting. Almost all studies (79\%) used the incidence based approach. Almost half of the studies used age-weighting (42\%), whereas more than $50 \%$ of the studies used discounting. Two thirds of the foodborne burden of disease studies (67\%) analyzed the effect of uncertainty as a result of possible imprecision in the parameter values.

\subsection{Epidemiological data}

To assess the burden of disease of a particular agent requires high quality data. The diverse range of data sources, literature research and/or expert opinion data that are used pointed out that incidence and prevalence data regarding foodborne disease are particularly

a

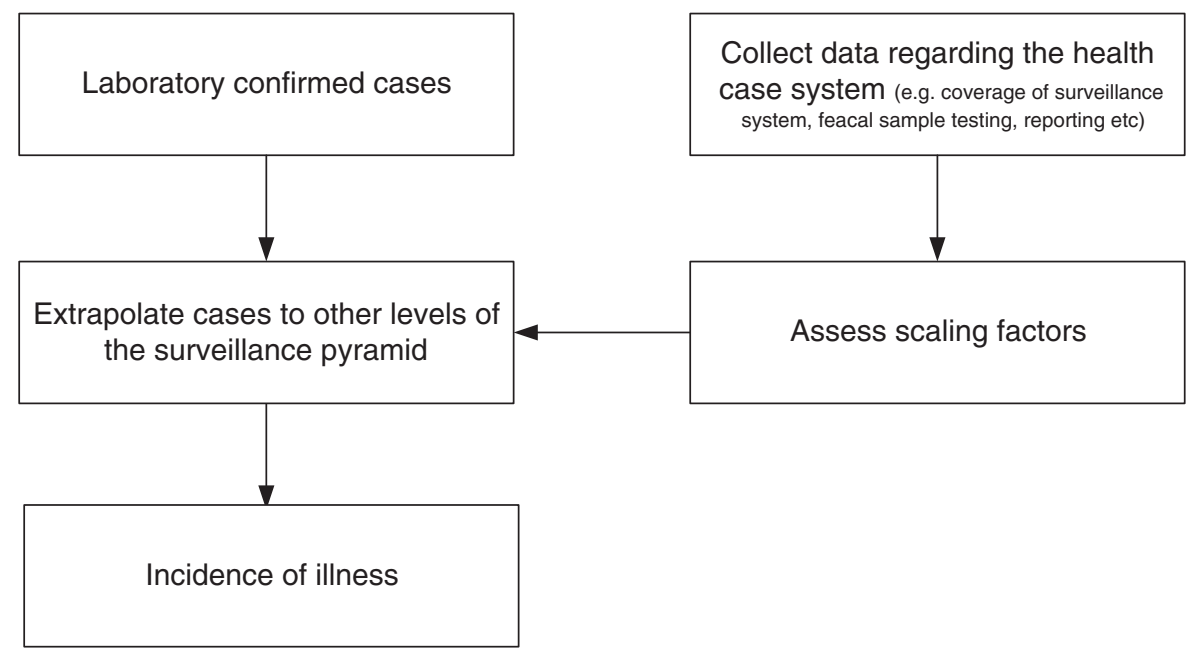

b

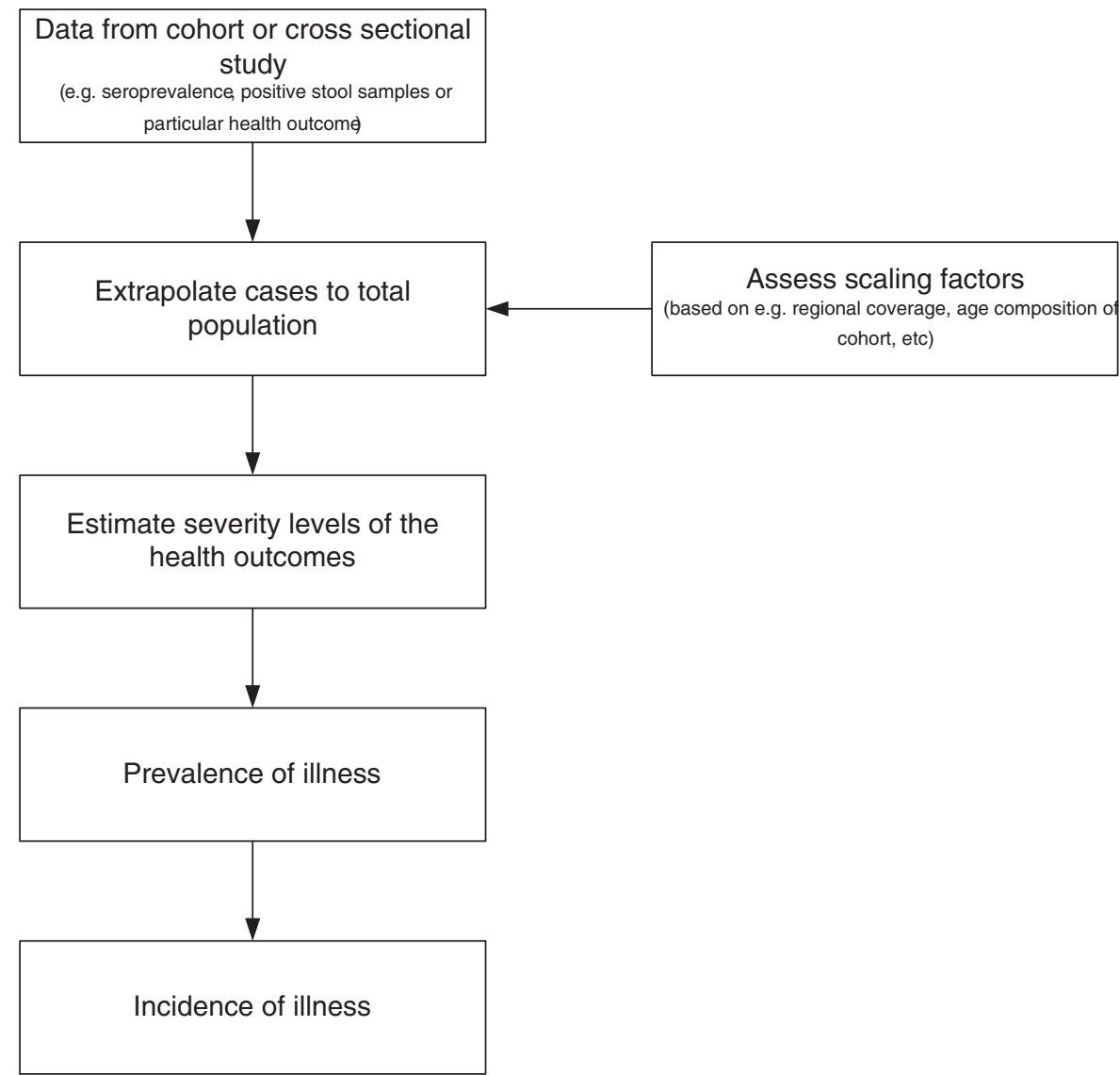

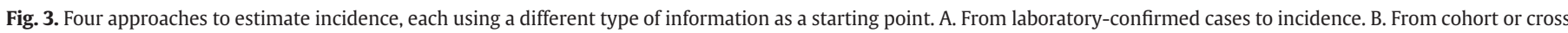
sectional data to incidence. C. From syndrome surveillance or survey data to incidence. D. From exposure data to incidence. 
C

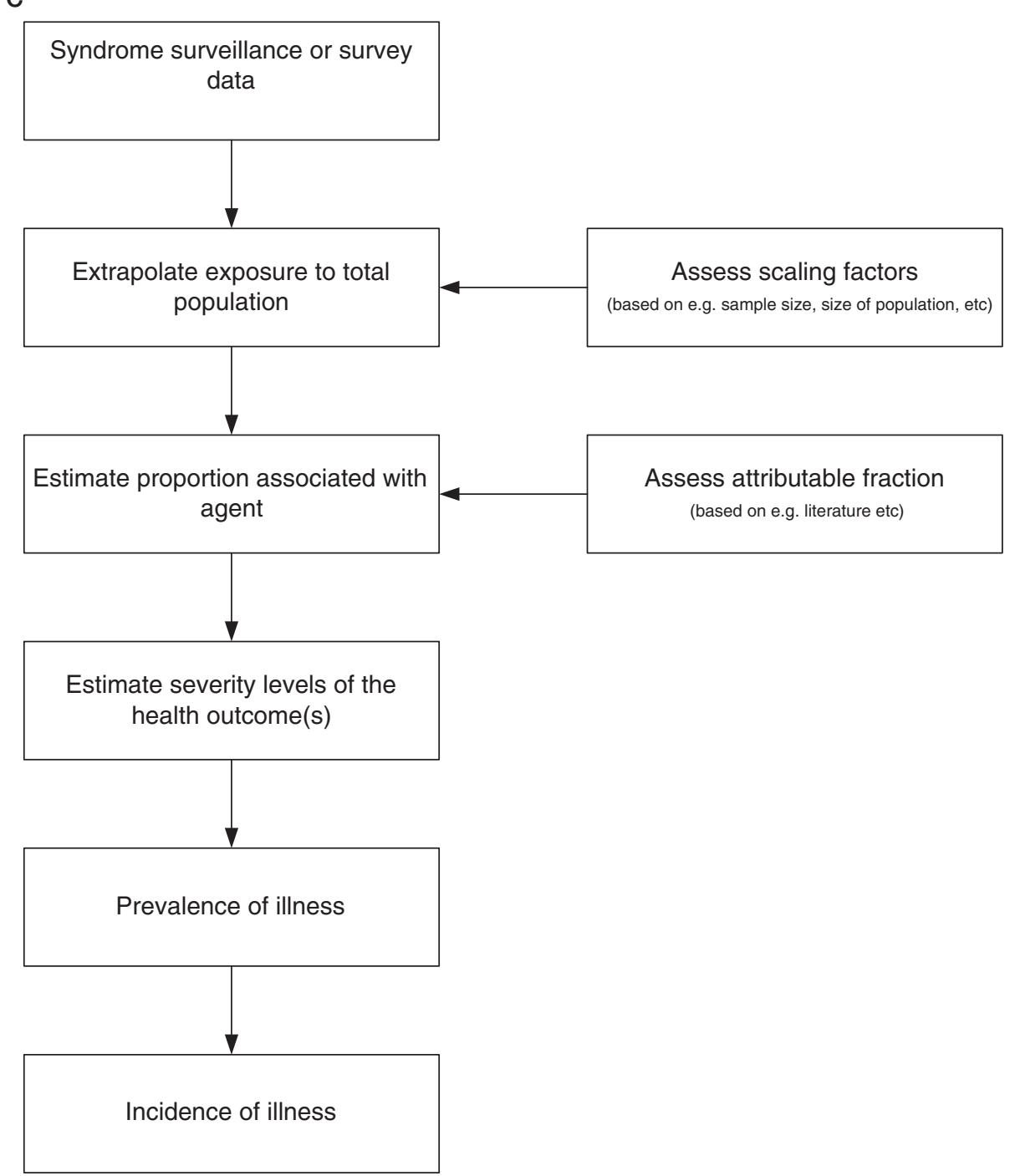

Fig. 3 (continued).

hard to come by. With regards to the foodborne disease model, most of the included studies used the agent-based approach. By nature of its setup the agent-based approach allows an estimate of the burden of disease due to a certain agent. The advantage of this approach is that this estimate includes both acute health effects as well as sequelae, even if these are delayed.

Regarding the data sources four approaches to arrive at incidence data could be discerned, each using a distinct type of information as a starting point, e.g. data from laboratory surveillance or exposure data. Dependent on the type of information that was used as a starting point, data was extrapolated to other levels of the surveillance pyramid or geographically regional data was extrapolated to the whole population using scaling factors. These scaling factors were based on surveys, expert opinion or assumptions. In many cases, the information for the scaling factors was limited or crude, which raises questions about the validity of the extrapolations. Nonetheless, many studies examined structural uncertainty of assumptions by means of scenario analysis.

The data quality and data gaps were also highly dependent on the information that was used as a starting point. Frequently found data gaps concerned severity distribution of the health outcomes, proportion of cases that develop sequelae and mortality rates. Moreover, studies were sometimes restricted to one or two health outcomes rather than all health outcomes that may be caused by the agent. In case of missing data, assumptions were made which were often derived from literature or based on expert opinion.

\subsection{Methodological choices for DALY calculations}

There are several applications for burden of disease studies, ranging from comparison of diseases in the same population and comparison of the overall health status between two or more populations through analysis of the benefits of health interventions for use in cost-effectiveness studies and provision of information to assist in setting priorities for health planning, public health programs and research (Mathers et al., 2001). Model choices affect the outcomes of the analysis, yet the importance of this effect is dependent on the application of the study. If the ultimate goal of the study is risk ranking of foodborne diseases, then model choices are less important; it is their consistency of application that is important. If the burden estimates are to be compared with those for other diseases, or across regions or countries then the model choices are more important.

The calculation of the morbidity component of the burden of disease, expressed in YLD, depends highly on the specific model being applied and the type of data underlying this model. Variation in 
d

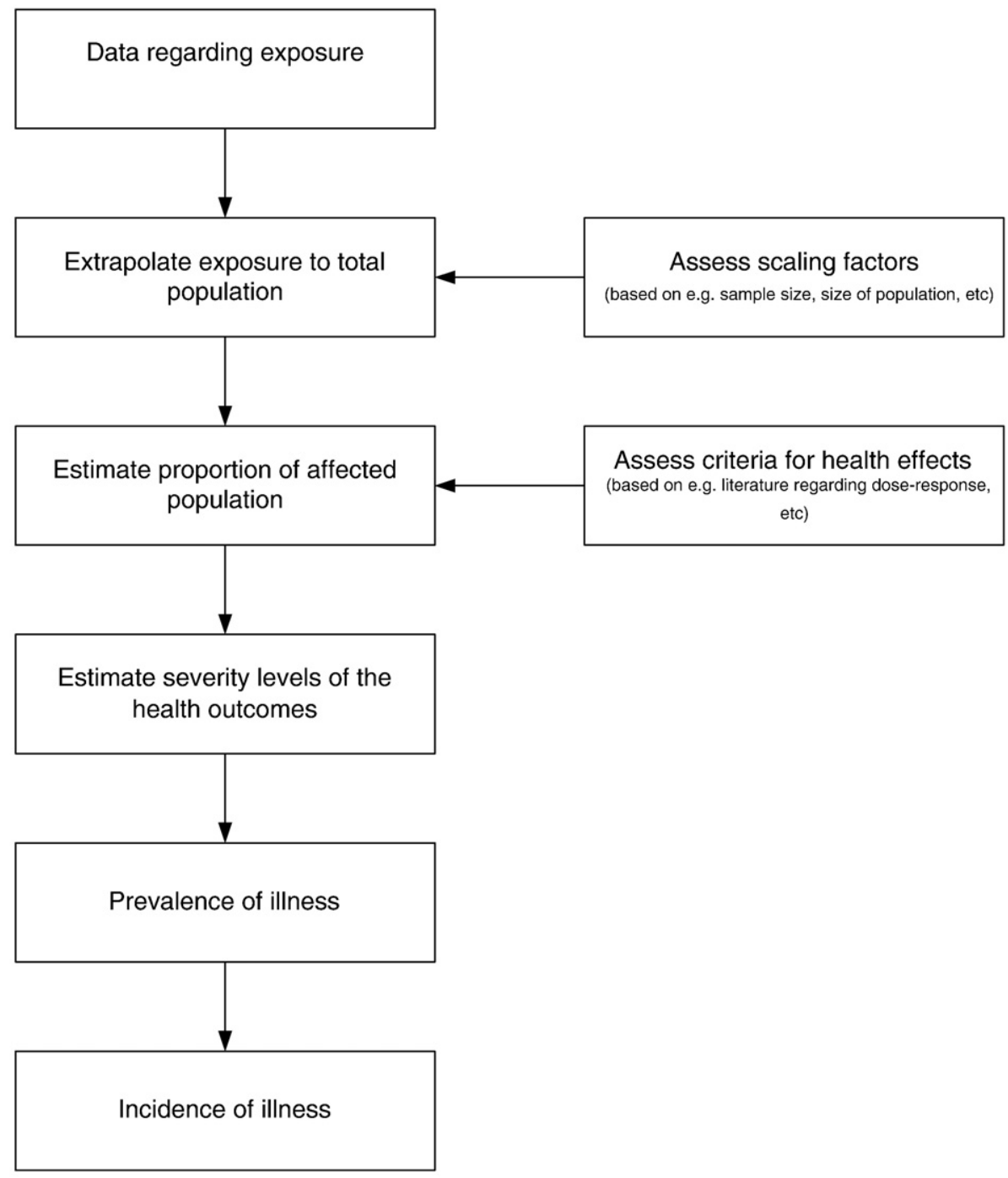

Fig. 3 (continued).

methodological choices included the disability weights and application of age-weighting and discounting.

Most studies used the GBD disability weights, in many cases supplemented by disability weights from the Dutch disability weights set. The GBD disability weights cover a wider range of conditions than covered by Dutch disability weights, but are generally less specific in terms of the disease and sequelae categories to which they refer. Several studies reported that there were no disability weights available for particular health outcomes. In these cases, disability weights of health outcomes with similar health effects were used. For other health outcomes, disability weights from different sets are available. To ensure a uniform method to assess burden of foodborne disease, it should be decided which set of disability weights is preferred for foodborne burden of disease studies. Also, missing disability weights for health outcomes caused by foodborne agents should be identified and proxy-disability weights should be proposed (e.g. adopt disability weights from other sets of disability weights, or use a disability weight of a disease with similar symptoms and impact).

In the original GBD study discounting and age-weighting are applied. However, both age-weighting and discounting have been disputed. The drawback of age-weighting is that it has been disputed on equity grounds (higher weights are assigned to people between 18 and 55 years old), the absence of empirical foundation and validation, and because the age weights do not convey actual social values because this practice is controversial (Anand and Hanson, 1997; Johanneson and Johansson, 1997).

Discounting has been disputed because its application results in a lower efficiency of prevention programs, whereas not discounting, or the use of a low discount rate-lower than the discount rate used for the costs-favor preventive measures due to benefit in the far future (Drummond et al., 1997). This discussion is reflected in different choices to use discounting and age-weighting between the included studies in our review. We recommend reporting both discounted and undiscounted DALYs.

When focusing on a single cause of disease in a population, it should be noted that foodborne agents may be linked to health outcomes with have multiple causative agents and risk factors. In these cases it is important to define envelopes by estimating total mortality and morbidity for a population/country. Defining mortality and/or morbidity envelopes in burden of foodborne disease studies ensures that the cause-specific estimates add to the total mortality and morbidity by age and sex and avoids systematic underestimation or double counting of deaths and morbidity (Murray and Lopez, 1996). This is particularly important because the majority of studies used case-fatality ratios rather than vital registration data to calculate mortality and an extrapolation of available disease data in order to 
Table 3

Methods used to calculate YLL and YLD in burden of disease studies related to foodborne disease.

\begin{tabular}{|c|c|c|c|c|c|c|c|c|c|c|c|c|}
\hline \multirow[t]{2}{*}{ Author, year } & \multirow[b]{2}{*}{$\begin{array}{l}\text { Incidence or } \\
\text { prevalence based } \\
\text { approach }\end{array}$} & \multicolumn{6}{|c|}{ General burden of disease methods } & \multirow{2}{*}{$\frac{\text { YLL methodology }}{\text { Which life tables used? }}$} & \multicolumn{4}{|c|}{ YLD methodology } \\
\hline & & $\begin{array}{l}\text { Agent, outcome or } \\
\text { risk factor-based? }\end{array}$ & $\begin{array}{l}\text { Type of } \\
\text { agent }\end{array}$ & $\begin{array}{l}\text { Age } \\
\text { weighting }\end{array}$ & Discounting & $\begin{array}{l}\text { Were missing } \\
\text { values handled? }\end{array}$ & $\begin{array}{l}\text { Sensitivity/ } \\
\text { uncertainty } \\
\text { analysis }\end{array}$ & & $\begin{array}{l}\text { Disability } \\
\text { weights }\end{array}$ & $\begin{array}{l}\text { Sequelae } \\
\text { include? }\end{array}$ & $\begin{array}{l}\text { Distribution } \\
\text { by severity? }\end{array}$ & $\begin{array}{l}\text { Adjustment for } \\
\text { comorbidity }\end{array}$ \\
\hline GBD approach & Incidence & Outcome-based & n.a. & $\mathbf{Y}$ & $\mathbf{Y}$ & $\mathbf{Y}$ & $\mathbf{Y}$ & $\begin{array}{l}\text { Standard West } 25 \text { (males) } \\
\text { and } 26 \text { (females) }\end{array}$ & GBD & $\mathbf{Y}$ & $\mathbf{N}$ & $\mathbf{N}$ \\
\hline Budke et al. (2004) & Incidence & Agent-based & Parasitic & $\mathrm{Y}$ & $\mathrm{Y}$ & $\mathrm{Y}$ & $\mathrm{Y}$ & $\begin{array}{l}\text { Standard West } 25 \text { (females) } \\
\text { and } 26 \text { (males) }\end{array}$ & GBD, DDW & $\mathrm{Y}$ & Y & $\mathrm{N}$ \\
\hline Fewtrell et al. (2004) & Incidence & Agent-based & Chemical & $\mathrm{N}$ & $\mathrm{N}$ & - & - & - & - & - & - & - \\
\hline Fewtrell et al. (2005) & Prevalence & Agent-based & Chemical & $\mathrm{Y}$ & $\mathrm{Y}$ & n.a. & $\mathrm{Y}$ & n.a. & n.a. & n.a. & $\mathrm{Y}$ & $\mathrm{N}$ \\
\hline Furst et al. (2012) & Prevalence & Agent-based & Parasitic & $\mathrm{N}$ & $\mathrm{N}$ & n.a. & $\mathrm{Y}$ & n.a. & GBD & $\mathrm{Y}$ & n.a. & $\mathrm{N}$ \\
\hline Gkogka et al. (2011) & Incidence & Agent-based & Enteric, parasitic & $\mathrm{N}$ & $\mathrm{N}$ & n.a. & $\mathrm{Y}$ & Standard life tables for Greece & GBD, DDW & $\mathrm{Y}$ & $\mathrm{Y}$ & $\mathrm{N}$ \\
\hline Guerrant et al. (2002) & Incidence & Outcome-based & - & $\mathrm{Y}$ & $\mathrm{Y}$ & n.a. & n.a. & n.a. & GBD & $\mathrm{Y}$ & n.a. & $\mathrm{N}$ \\
\hline Haagsma et al. (2008) & Incidence & Agent-based & Enteric & $\mathrm{N}$ & $\mathrm{Y}$ & $\mathrm{Y}$ & $\mathrm{Y}$ & $\begin{array}{l}\text { Standard life tables for } \\
\text { Netherlands }\end{array}$ & DDW & $\mathrm{Y}$ & $\mathrm{Y}$ & $\mathrm{N}$ \\
\hline Havelaar et al. (2000) & Incidence & Agent-based & Enteric & $\mathrm{N}$ & $\mathrm{Y}$ & $\mathrm{Y}$ & $\mathrm{Y}$ & $\begin{array}{l}\text { Standard West } 25 \text { (females) } \\
\text { and } 26 \text { (males) }\end{array}$ & GBD, EQ5D & $\mathrm{Y}$ & $\mathrm{Y}$ & $\mathrm{N}$ \\
\hline Havelaar et al. (2004) & Incidence & Agent-based & Enteric & $\mathrm{N}$ & Y & $\mathrm{Y}$ & $\mathrm{Y}$ & $\begin{array}{l}\text { Standard life tables for } \\
\text { Netherlands }\end{array}$ & GBD, DDW & $\mathrm{Y}$ & $\mathrm{Y}$ & $\mathrm{Y}$ \\
\hline $\begin{array}{l}\text { Havelaar et al. } \\
\text { (2007b) }\end{array}$ & Incidence & Agent-based & Parasitic & $\mathrm{N}$ & $\mathrm{Y}$ & n.a. & $\mathrm{Y}$ & $\begin{array}{l}\text { Standard West } 25 \text { (females) } \\
\text { and } 26 \text { (males) }\end{array}$ & DDW & $\mathrm{Y}$ & $\mathrm{Y}$ & $\mathrm{N}$ \\
\hline Havelaar et al. (2012) & Incidence & Agent-based & Enteric, parasitic & $\mathrm{N}$ & Y & $\mathrm{Y}$ & $\mathrm{Y}$ & $\begin{array}{l}\text { Standard West } 25 \text { (females) } \\
\text { and } 26 \text { (males) }\end{array}$ & GBD, DDW & $\mathrm{Y}$ & $\mathrm{Y}$ & Y \\
\hline Kortbeek et al. (2009) & Incidence & Agent-based & Parasitic & $\mathrm{N}$ & n.a. & n.a. & $\mathrm{Y}$ & $\begin{array}{l}\text { Standard life tables for } \\
\text { Netherlands }\end{array}$ & n.a. & $\mathrm{Y}$ & $\mathrm{N}$ & $\mathrm{N}$ \\
\hline Lake et al. (2010) & Incidence & Agent-based & Enteric & $\mathrm{N}$ & $\mathrm{Y}$ & n.a. & $\mathrm{Y}$ & $\begin{array}{l}\text { Standard life tables for New } \\
\text { Zealand }\end{array}$ & DDW, GBD & $\mathrm{Y}$ & $\mathrm{Y}$ & $\mathrm{N}$ \\
\hline Lewin et al. (2007) & Incidence & Risk factor-based & - & $\mathrm{N}$ & $\mathrm{N}$ & - & - & - & - & - & - & - \\
\hline Lokuge et al. (2004) & Incidence & Agent-based & Chemical & $\mathrm{Y}$ & $\mathrm{Y}$ & n.a. & n.a. & n.a. & - & - & - & - \\
\hline Mathers et al. (2007) & Incidence & Outcome-based & - & $\mathrm{Y}$ & $\mathrm{Y}$ & n.a. & n.a. & $\begin{array}{l}\text { Standard West } 25 \text { (females) } \\
\text { and } 26 \text { (males) }\end{array}$ & GBD & $\mathrm{Y}$ & n.a. & $\mathrm{Y}$ \\
\hline Nafar et al. (2008) & Incidence & Outcome-based & - & $\mathrm{Y}$ & $\mathrm{Y}$ & $\mathrm{Y}$ & n.a. & Standard life tables for Iran & Iranian DW & - & n.a. & $\mathrm{N}$ \\
\hline Praet et al. (2009) & Incidence & Agent-based & Parasitic & $\mathrm{Y}$ & $\mathrm{Y}$ & n.a. & $\mathrm{Y}$ & $\begin{array}{l}\text { Standard West } 25 \text { (females) } \\
\text { and } 26 \text { (males) }\end{array}$ & GBD & $\mathrm{Y}$ & $\mathrm{N}$ & $\mathrm{N}$ \\
\hline Pruss et al. (2002) & Incidence & Risk factor-based & - & $\mathrm{Y}$ & $\mathrm{Y}$ & n.a. & n.a. & $\begin{array}{l}\text { Standard West } 25 \text { (females) } \\
\text { and } 26 \text { (males) }\end{array}$ & GBD & n.a. & $\mathrm{N}$ & $\mathrm{N}$ \\
\hline Reij et al. (2009) & Incidence & Agent-based & Enteric & $\mathrm{N}$ & $\mathrm{N}$ & n.a. & $\mathrm{Y}$ & $\begin{array}{l}\text { Standard West } 25 \text { (females) } \\
\text { and } 26 \text { (males) }\end{array}$ & GBD & $\mathrm{Y}$ & $\mathrm{N}$ & $\mathrm{N}$ \\
\hline Torgerson et al. (2008) & Incidence & Agent-based & Parasitic & $\mathrm{Y}$ & $\mathrm{Y}$ & $\mathrm{Y}$ & $\mathrm{Y}$ & Swiss life tables & DDW & $\mathrm{Y}$ & $\mathrm{Y}$ & $\mathrm{N}$ \\
\hline Valent et al. (2004) & Incidence & Chemical & Chemical & $\mathrm{Y}$ & $\mathrm{Y}$ & n.a. & $\mathrm{Y}$ & n.a. & DDW, GBD & $\mathrm{N}$ & n.a. & $\mathrm{N}$ \\
\hline Van Lier et al. (2007) & Incidence & Agent-based & Enteric & $\mathrm{N}$ & $\mathrm{N}$ & n.a. & $\mathrm{Y}$ & $\begin{array}{l}\text { Standard West } 25 \text { (females) } \\
\text { and } 26 \text { (males) }\end{array}$ & GBD & $\mathrm{Y}$ & $\mathrm{N}$ & $\mathrm{N}$ \\
\hline Verhoef et al. (2012) & Incidence & Agent-based & Enteric & $\mathrm{N}$ & Y & n.a. & $\mathrm{Y}$ & $\begin{array}{l}\text { Standard West } 25 \text { (females) } \\
\text { and } 26 \text { (males) }\end{array}$ & DDW & $\mathrm{N}$ & $\mathrm{Y}$ & $\mathrm{Y}$ \\
\hline
\end{tabular}

na. $=$ not available, $-=$ not applicable

Dutch Disability weights, EQ5Ddw = EQ5D disability weights. 
assess the incidence in the population. Strikingly, however, none of the burden of disease studies mentioned the use of a mortality envelope.

An aspect related to mortality due to foodborne diseases is the inclusion of stillbirth and fetal loss in disease burden estimates. Several foodborne agents, such as parasites (e.g. Toxoplasma gondii), enteric pathogens (e.g. Listeria monocytogenes) and chemical contaminants (e.g. arsenic exposure) may cause stillbirth and/or fetal death. The current situation is that a baby who dies just after birth counts in the GBD metrics. However, a baby who dies in the third trimester or during labor does not count, because of ethical issues and for practical reasons (Bhutta et al., 2011; Lawn et al., 2011; Murray and Lopez, 1996; Pattinson et al., 2011). Therefore, currently there are no established methods to account for fetal loss. A major practical problem is that stillbirths are not routinely recorded in surveys. Furthermore, if data are recorded they are often reported as perinatal mortality, which reduces visibility and might obfuscate differences in reporting and systematic misclassification (Lawn et al., 2011; Pattinson et al., 2011). Jamison et al. have performed a sensitivity analysis of an approach that incorporates stillbirths in the GBD estimates (Jamison et al., 2006). Havelaar et al. and Kortbeek et al. included losses of a viable fetus (more than 24 weeks in The Netherlands) in their estimates of the burden of congenital toxoplasmosis (Havelaar et al., 2007b; Kortbeek et al., 2009).

\subsection{Uncertainty}

The precision of DALY estimates is not quantifiable in the usual statistical sense of deriving a confidence interval, because the precision varies across diseases and depends highly on the specific approach being applied and the type of data underlying this model. Uncertainty in burden of disease studies may result from data uncertainties, such as statistical uncertainty due to small sample size, systematic uncertainty or lack of data. This uncertainty is dealt with by uncertainty analysis, which tests whether plausible changes in values of the main variables affect the results of the analysis. These analyses show how, for instance, the effect of uncertainty in the disability weights and/or uncertainty in the incidence data.

\section{Conclusions}

Accurate quantification of the population burden of disease is important for resource allocation and the identification of important prevention priorities. However, a major challenge that is met when performing foodborne burden of disease studies is lack of available data. Our review showed that a wide variety of sources were used to assess mortality, morbidity and disability and that profound statistical modelling was often needed to extrapolate the data to other levels of the surveillance pyramid and/or the whole population under study. Secondly, we found that large differences existed in burden of disease methodology, although most studies used the incidence-based approach. This dominance of the incidence-based approach is strongly related to the perspective of the study. Most studies used an agent-based approach to assess the health impact of a particular agent and this perspective requires an incidence-based approach. The methodological choices that are made and the importance of the effect of methodological choices on the burden of disease estimates are dependent on the application of the study. Furthermore, our review showed that the majority of the included studies analyzed the effect of model, structural and/or parameter uncertainty.

Awareness of epidemiological and methodological rigor between burden of disease studies using the DALY approach is a critical priority for advancing burden of disease studies. Harmonization of the methodology that is used, high quality data and advanced modeling techniques can enlarge the detection of real variation in DALY outcomes between populations or over time. This harmonization can be achieved by identifying substantial data gaps and uncertainty and establish which sequelae of foodborne disease agents should be included in burden of disease calculations.

\section{References}

Anand, S., Hanson, K., 1997. Disability-adjusted life years: a critical review. Journal of Health Economics 16, 685-702.

Bhutta, Z.A. Yakoob, M.Y. Lawn, J.E, Rizvi, A., Friberg I.K, Weissman, E, Buchmann, E Goldenberg, R.L., 2011. Stillbirths: what difference can we make and at what cost? Lancet 377, 1523-1538.

Bilcke, J., Beutels, P., Brisson, M., Jit, M., 2011. Accounting for methodological, structural, and parameter uncertainty in decision-analytic models: a practical guide. Medical Decision Making 31, 675-692.

Budke, C.M., Jiamin, Q., Zinsstag, J., Qian, W., Torgerson, P.R., 2004. Use of disability adjusted life years in the estimation of the disease burden of echinococcosis for a high endemic region of the Tibetan plateau. The American Journal of Tropical Medicine and Hygiene 71, 56-64.

Drummond, M.F., O'Brien, B.J., Stoddart, G.L., Torrance, G.W., 1997. Methods for the Economic Evaluation of Health Care Programmes. Oxford Medical Publications, Oxford, U.K.

Fewtrell, L.J., Pruss-Ustun, A., Landrigan, P., Ayuso-Mateos, J.L., 2004. Estimating the global burden of disease of mild mental retardation and cardiovascular diseases from environmental lead exposure. Environmental Research 94, 120-133.

Fewtrell, L., Fuge, R., Kay, D., 2005. An estimation of the global burden of disease due to skin lesions caused by arsenic in drinking water. Journal of Water and Health 3 , 101-107.

Furst, T., Keiser, J., Utzinger, J., 2012. Global burden of human food-borne trematodiasis: a systematic review and meta-analysis. Lancet Infectious Disease $12,210-221$.

Gkogka, E., Reij, M.W., Havelaar, A.H., Zwietering, M.H., Gorris, L.G.M., 2011. Risk-based estimate of effect of foodborne diseases on public health, Greece. Emerging Infectious Diseases 17, 1581-1590.

Guerrant, R.L., Kosek, M., Lima, A.A., Lorntz, B., Guyatt, H.L., 2002. Updating the DALYs for diarrhoeal disease. Trends in Parasitology 18, 191-193.

Haagsma, J.A., Havelaar, A.H., Janssen, B.M., Bonsel, G.J., 2008. Disability Adjusted Life Years and minimal disease: application of a preference-based relevance criterion to rank enteric pathogens. Population Health Metrics 6, 7.

Havelaar, A.H., de Wit, M.A., van Koningsveld, R., van Kempen, E., 2000. Health burden in the Netherlands due to infection with thermophilic Campylobacter spp. Epidemiology and Infection 125, 505-522.

Havelaar, A.H., Van Duynhoven, Y.T.P.H., Nauta, M.J., Bouwknegt, M., Heuvelink, A.E., De Wit, G.A., Nieuwenhuizen, M.G., van de Kar, N.C., 2004. Disease burden in The Netherlands due to infections with Shiga toxin-producing Escherichia coli 0157. Epidemiology and Infection 132, 467-484.

Havelaar, A.H., Braunig, J., Christiansen, K., Cornu, M., Hald, T., Mangen, M.J., Molbak, K., Pielaat, A., Snary, E., Van Pelt, W., Velthuis, A., Wahlstrom, H., 2007a. Towards an integrated approach in supporting microbiological food safety decisions. Zoonoses and Public Health 54, 103-117.

Havelaar, A.H., Kemmeren, J.M., Kortbeek, L.M., 2007b. Disease burden of congenita toxoplasmosis. Clinical Infectious Diseases 44, 1467-1474.

Havelaar, A.H., van Rosse, F., Bucura, C., Toetenel, M.A., Haagsma, J.A., Kurowicka, D., Heesterbeek, J.H., Speybroeck, N., Langelaar, M.F., van der Giessen, J.W., Cooke, R.M., Braks, M.A., 2010. Prioritizing emerging zoonoses in the Netherlands. PLoS One 5, e13965.

Havelaar, A.H., Haagsma, J.A., Mangen, M.J., Kemmeren, J.M., Verhoef, L.P., Vijgen, S.M., Wilson, M., Friesema, I.H., Kortbeek, L.M., van Duynhoven, Y.T.P.H., van Pelt, W. 2012. Disease burden of foodborne pathogens in the Netherlands, 2009. International Journal of Food Microbiology 156, 231-238.

Jamison, D.T., Shahid-Salles, S.A., Jamison, J., Lawn, J.E., Zupan, J., 2006. Incorporating deaths near the time of birth into estimates of the Global Burden of Disease. In Lopez, A.D., Mathers, C.D., Ezzati, M., Jamison, D.T., Murray, C.J.L. (Eds.), Global Burden of Disease and risk factors. The World Bank and Oxford University Press, New York.

Johanneson, M., Johansson, P.O., 1997. Is the valuation of a QALY gained independent of age? Some empirical evidence. Journal of Health Economics 16, 589-599.

Kay, D., Prüss, A., Corvalán, C., 2000. Methodology for Assessment of Environmental Burden of Disease. World Health Organization, Geneva.

Kortbeek, L.M., Hofhuis, A., Nijhuis, C.D., Havelaar, A.H., 2009. Congenital toxoplasmosis and DALYs in the Netherlands. Memórias do Instituto Oswaldo Cruz 104, 370-373.

Kretzschmar, M., Mangen, M.J., Pinheiro, P., Jahn, B., Fevre, E.M., Longhi, S., Lai, T., Havelaar, A.H., Stein, C., Cassini, A., Kramarz, P., 2012. New methodology for estimating the burden of infectious diseases in Europe. PLoS Medicine 9, e1001205.

Lake, R.J., Cressey, P.J., Campbell, D.M., Oakley, E., 2010. Risk ranking for foodborne microbial hazards in New Zealand: burden of disease estimates. Risk Analysis 30, $743-752$.

Lawn, J.E., Blencowe, H., Pattinson, R., Cousens, S., Kumar, R., Ibiebele, I., Gardosi, J., Day, L.T., Stanton, C., 2011. Stillbirths: Where? When? Why? How to make the data count? Lancet 377, 1448-1463.

Lewin, S., Norman, R., Nannan, N., Thomas, E., Bradshaw, D., 2007. Estimating the burden of disease attributable to unsafe water and lack of sanitation and hygiene in South Africa in 2000. South African Medical Journal 97, 755-762. 
Lokuge, K.M., Smith, W., Caldwell, B., Dear, K., Milton, A.H., 2004. The effect of arsenic mitigation interventions on disease burden in Bangladesh. Environmental Health Perspectives 112, 1172-1177.

Maldonado, G., Greenland, S., 2002. Estimating causal effects. International Journal of Epidemiology 31, 422-429.

Mangen, M.J., Batz, M.B., Kasbohrer, A., Hald, T., Morris Jr., J.G., Taylor, M., Havelaar, A.H., 2010. Integrated approaches for the public health prioritization of foodborne and zoonotic pathogens. Risk Analysis 30, 782-797.

Mathers, C.D., Vos, T., Lopez, A.D., Salomon, J.A., Ezzati, M., 2001. National burden of diseases studies: a practical guide, WHO Global Program on Evidence for Health Policy, Edition 2.0. World Health Organization, Geneva.

Mathers, C.D., Ezzati, M., Lopez, A.D., 2007. Measuring the burden of neglected tropical diseases: the global burden of disease framework. PLoS Neglected Tropical Diseases 1, e114.

McKimmie, T., Szurmak, J., 2002. Beyond Grey Literature: How grey questions can drive research. Journal of Agricultural \& Food Information 4, 71.

Murray, C.J., 1994. Quantifying the burden of disease: the technical basis for disabilityadjusted life years. Bulletin of the World Health Organization 72, 429-445.

Murray, C.J., Acharya, A.K., 1997. Understanding DALYs (disability-adjusted life years) Journal of Health Economics 16, 703-730.

Murray, C.J.L., Lopez, A.D., 1996. The Global Burden of Disease: A Comprehensive Assessment of Mortality and Disability From Diseases, Injuries and Risk Factors in 1990 and Projected to 2020. Harvard University Press, Cambridge.

Nafar, M., Mousavi, S.M., Mahdavi-Mazdeh, M., Pour-Reza-Gholi, F., Firoozan, A. Einollahi, B., Lessan-Pezeshki, M.L., Asbaghi-Namini, S., Farrokhi, F., 2008. Burden of chronic kidney disease in Iran: a screening program is of essential need. Iranian Journal of Kidney Diseases 2, 183-192.

Pattinson, R., Kerber, K., Buchmann, E., Friberg, I.K., Belizan, M., Lansky, S., Weissman, E., Mathai, M., Rudan, I., Walker, N., Lawn, J.E., 2011. Stillbirths: how can health systems deliver for mothers and babies? Lancet 377, 1610-1623.

Praet, N., Speybroeck, N., Manzanedo, R., Berkvens, D., Nsame Nforninwe, D., Zoli, A. Quet, F., Preux, P.M., Carabin, H., Geerts, S., 2009. The disease burden of Taenia solium cysticercosis in Cameroon. PLoS Neglected Tropical Diseases 3, e406.
Pruss, A., Kay, D., Fewtrell, L., Bartram, J., 2002. Estimating the burden of disease from water, sanitation, and hygiene at a global level. Environmental Health Perspectives $110,537-542$.

Reij, M.W., Jongenburger, I., Gkogka, E., Gorris, L.G.M., Zwietering, M.H., 2009. Perspective on the risk to infants in the Netherlands associated with Cronobacter spp. occurring in powdered infant formula. International Journal of Food Microbiology 136, 232-237.

Tauxe, R.V., Doyle, M.P., Kuchenmuller, T., Schlundt, J., Stein, C.E., 2010. Evolving public health approaches to the global challenge of foodborne infections. International Journal of Food Microbiology 139 (Suppl. 1), S16-S28.

Torgerson, P.R. Schweiger, A., Deplazes, P., Pohar, M., Reichen, J. Ammann, R.W., Tarr, P.E., Halkik, N., Mullhaupt, B., 2008. Alveolar echinococcosis: from a deadly disease to a well-controlled infection. Relative survival and economic analysis in Switzerland over the last 35 years. Journal of Hepatology 49, 72-77.

Valent, F. Little, D., Tamburlini, G., Barbone, F., 2004. Burden of Disease Attributable to Selected Environmental Factors and Injuries Among Europe's Children and Adolescents. World Health Organization, Geneva.

Van Lier, E.A., Havelaar, A.H., 2007. Disease Burden of Infectious Diseases in Europe: A Pilot Study. RIVM, Bilthoven.

Van Lier, E.A., Havelaar, A.H., Nanda, A., 2007. The burden of infectious diseases in Europe: a pilot study. Eurosurveillance 12, E3-E4.

Verhoef, L. Koopmans, M., van Pelt, W. Duizer, E, Haagsma, J.A. Werber, D, van Asten, L., Havelaar, A.H., 2012. The estimated disease burden of norovirus in The Netherlands. Epidemiology and Infection 1-11.

WHO, 2007. WHO Initiative to Estimate the Global Burden of Foodborne Diseases. First formal meeting of the Foodborne Disease Burden Epidemiology Reference Group (FERG). First formal meeting of the Foodborne Disease Burden Epidemiology Reference Group. World Health Organization, Geneva.

WHO, 2008. WHO Initiative to Estimate the Global Burden of Foodborne Diseases. Second formal meeting of the Foodborne Disease Burden Epidemiology Reference Group (FERG). World Health Organization, Geneva.

Worldbank, 1993. World Development Report 1993. Investing in Health Oxford University Press, New York. 